UDC 336.148:338.244.47

DOI: https://doi.org/10.32840/2522-4263/2021-2-8

Tarasenko Olena

PhD in Economics, Associate Professor Donetsk State University of Management Veretelnyk Svitlana

Senior Lecturer

Donetsk State University of Management

Vahis Olga

Head of the Department of Financial and Budget Policy of Zaporizhzhia City Council

Тарасенко О.Ю. кандидат еконолічних наук, доцент, Донецький державний університет управління

Верительник C.M. старший викладач кафедри публічного управління та адліністрування Донецького державного університету управління

Baric O.A.

директор департаленту фінансової та бюджетної політики

Запорізької міської ради

\title{
EXPERIENCE OF FOREIGN COUNTRIES IN PUBLIC FINANCIAL CONTROL IN TERMS OF DECENTRALIZATION
}

\section{ДОСВІД ІНШИХ КРАЇН У СФЕРІ ДЕРЖАВНОГО ФІНАНСОВОГО КОНТРОЛЮ В УМОВАХ ДЕЦЕНТРАЛІЗАЦІї}

\begin{abstract}
ANNOTATION
The state control in financial management is one of the most effective tools that ensures the public financial resources management effectiveness. In other words, it is the activity of public authorities and management at all levels, established by law to identify, supress and prevent: abuses and mistakes in the state monetary and material resources management; violations of financial and economic legislation; flaws in the organization of financial and economic management systems of state organizations and their associations, organizations with state participation or mainly related to the activities of the state; threats to economic (including financial) security of the state. The article analyzes the conditions and models of state and municipal financial control in leading developed countries. Moreover, the systems of organization of financial management in developed countries were considered. The ways to apply foreign experience in Ukraine regarding the reforms in state and municipal financial control systems were studied.

Key words: financial control, state financial control, municipal financial control, local finances, decentralization, higher financial management bodies, budget, Chamber of Accounts.
\end{abstract}

\section{АНОТАЦІЯ}

Державний контроль у сфрері управління фрінансами - один з найбільш дієвих інструментів, що забезпечує ефективність управління державними фінансовими ресурсами. Іншими словами - це діяльність органів державної влади та управління всіх рівнів, встановлена законодавством з метою виявлення, припинення і попередження: зловживань і помилок в управлінні державними грошовими і матеріальними ресурсами; порушень фрінансово-господарського законодавства; вад в організації систем управління фінансово-господарською діяльністю державних організацій і їх об'єднань, організацій з державною участю або особливо пов'язаних з діяльністю держави; загроз економічній (у т.ч. фрінансовій) безпеці держави. Процес глобалізації, який став характерною рисою нашого часу, неминуче веде до виникнення більш тісної співпраці між державами у всіх значимих сфрерах діяльності. Безумовно, обмін досвідом у такій важливій галузі, як рух фінансових коштів важко переоцінити. Взаємодія відповідних структур різних країн у рамках організації фрінансового контролю, безперечно, $є$ одним з найбільш дієвих інструментів підвищення якості роботи, проведеної цими структурами. Сучасні тенденції світового розвитку зумовили необхідність пошуку збалансованості національних інтересів з інтересами глобального розвитку. Більшою мірою йдеться не лише за захист національних інтересів окремих країн, а й регіональних формувань. Такий підхід особливо актуальний для країн-членів Європейського Союзу - об'єднання, повноцінним членом якого поступово стає Україна. Зокрема, одним із пунктів вимог євроінтеграції для України виступало остаточне подолання корупції та бюджетних правопорушень. Це, у свою чергу, вимагає системного підходу до трансформаційних дій у сфрері державного фрінансового контролю. У статті проаналізовано умови та моделі організації державного і муніципального фінансового контролю в провідних розвинених країнах. Розглянуто системи організації фрінансового контролю в розвинених країнах. Приділено увагу можливостям застосування зарубіжного досвіду в Україні в контексті проведення рефрорм системи державного і муніципального фрінансового контролю.

Ключові слова: фрінансовий контроль, державний фрінансовий контроль, муніципальний фрінансовий контроль, місцеві фінанси, децентралізація, вищі органи фінансового контролю, бюджет, рахункова палата.

\section{АННОТАЦИЯ}

Государственный контроль в сфрере управления финансами - один из самых действенных инструментов, который обеспечивает эффективность управления государственными финансовыми ресурсами. Другими словами - это деятельность органов государственной власти и управления всех уровней, 
установленная законодательством с целью выявления, пресечения и предупреждения: злоупотреблений и ошибок в управлении государственными денежными и материальными ресурсами; нарушений финансово-хозяйственного законодательства; недостатков в организации систем управления финансово-хозяйственной деятельностью государственных организаций и их объединений, организаций с государственным участием или особо связанных с деятельностью государства; угроз экономической (в т.ч. финансовой) безопасности государства. В статье проанализированы условия и модели организации государственного и муниципального финансового контроля в ведущих развитых странах. Рассмотрены системы организации фринансового контроля в развитых странах. Уделено внимание возможностям применения зарубежного опыта в Украине в контексте проведения реформ системы государственного и муниципального финансового контроля.

Ключевые слова: финансовый контроль, государственный финансовый контроль, муниципальный финансовый контроль, местные финансы, децентрализация, высшие органы финансового контроля, бюджет, счетная палата.

Problem statement. Financial control plays a significant role in organizing the functioning of national financial systems. Any state exerts influence on socio-economic processes primarily through financial and budgetary policies, regulation of credit relations, the financial market and the state property system. Public authorities influence socio-economic processes through finances and the budget, allocating significant funds to meet social needs, and controlling their effectiveness. A system of effective public financial control of flows redistributed through budgets helps the government perform its functions effectively.

The public financial control system, which has developed in a particular state, has its characteristics related to society's historical aspects. Moreover, in world practice, public financial control bodies have long been an integral part of a democratic society and a mandatory public financial management element. The study of foreign experience in the public financial control implementation for our country is of considerable interest.

Actual scientific researches and issues analysis. Problems of state financial control in foreign countries are studied by V. Symonenko, N. Dorosh, L. Kinashchuk, J. Mazur, V. Melnychuk, L. Savchenko, O. Seleznyov, V. Katasonov, T. Gubanova, G. Fedotova, etc. Despite the scientific significance of their research, the introduction of leading foreign experience in the modern Ukrainian public financial control system needs further study.

The article aims to analyze the main approaches to the organization of public financial control in developed countries.

Statement of basic materials. Ukraine's desire to integrate into the world economic community requires forming a financial control system, which will comply with the Lima Declaration on Guiding Principles of Control, adopted in 1977 by the IX Congress of the International Organization of Supreme Audit Institutions (INTOSAI). Besides, the XX INTOSAI Congress also calls on all members of the International Organization of Supreme Audit Institutions to use INTOSAI standards as a basis for developing the standards. This is the starting point for any legislative reform of financial control.

The Lima Declaration indicates that to achieve rational and efficient public funds management it is necessary to create a supreme body of financial control in each state whose independence must be enshrined in law. This also applies to federal states, especially where territorial units have a high degree of autonomy, primarily in the fiscal sphere. In Ukraine, since 2014, there has been an accelerated process of financial decentralization, which is the formation of united territorial communities with greater financial independence. In this regard, the need to study developed countries' best practices with effective financial control systems is urgent.

In world practice, the main conditions for the public financial control effectiveness are considered to be the following:

1. Providing access to any relevant information. Public financial control bodies need quality information about the controlled object's actual condition or actions, unimpeded entry into any premises, seizure of documents, and sealing of objects.

2. Consistency, periodicity and complexity. The constant functioning of public financial control allows preventing the loss of financial resources, their misuse. Sustainability of financial management implies continuity of its implementation, sustainability and periodicity of control measures.

3. Compliance with state control mechanisms with the ability to implement the priority requirement. The most important objects with the most significant impact in ensuring the savings of public funds are inspected first.

4. The possibility of adapting the financial control system to solve new issues arising from changes in the state's internal and external conditions.

5. Coherence and interaction of control authorities.

6. Economic efficiency of the state financial control system.

7. Regulation of control activities, starting from planning and ending with the implementation of proposals based on control results, including standardization of processes and documentation. Without regulation and application of standard solutions, public financial control cannot work harmoniously in all its parts.

In the scientific literature, there are many approaches to the public financial control assessment in foreign countries.

Thus, O. Seleznyov believes that financial control systems differ depending on the reflection of state control in different states' constitutions. According to this criterion, he distinguishes the following methods: 
1) parliamentary - the country's constitution financial control is associated with the parliament activities. It also provides for the right of the latter to form an appropriate control body (similarly, in particular, the control system is developed in Russia);

2) judicial - the constitutional norms governing the activities of the financial control body are included in the section containing the basic standards of the functioning of the judiciary (for example, in Greece and Turkey);

3) specialized - the creation and regulation of the supreme body of financial control are reflected in the section of the constitution governing the activities of control bodies, including control over the functioning of the financial and budgetary system (Sweden, Ireland, Brazil, Poland);

4) presidential - the basic rules of organization and functioning of financial control are included in the constitution section on the president's authorities, including the powers to form a supreme control body (Portugal, Uzbekistan).

However, these models are rarely represented; they are often mixed, containing all these systems' elements in different proportions. Examples include the financial control systems of Austria, the Czech Republic, China (combining features of parliamentary and specialized systems), Italy and France (elements of parliamentary, presidential, judicial systems), and so on.

In the conditions of supranational integration, accompanied by the decentralization processes, the higher bodies of financial control expand the scope of their activities both quantitatively and qualitatively. The task of identifying violations and prosecuting managers at both the state and local levels comes to the fore.

It is necessary to consider the organization of public financial control on the example of the Republic of Austria as one of the member states of the European Union, which has a stable economy and sustainable socio-economic development. The beginning of decentralization in Austria began with the formation of a municipal districts' community. The term "commonwealth of municipal districts" means an administrative unit with its legal entity and performs various municipal districts' tasks on their behalf but under their responsibility. According to Article 116a of the Austrian Federation's Constitutional Law, municipal districts' communities may be created based on legal acts and the district's initiative. The tasks and authorities of communities may be sovereign (e.g., with the right to collect taxes) or private economic nature (e.g., provision of water supply). In addition to that, the delegation of powers to the Commonwealth of Municipal Districts does not have to jeopardize the districts' existence. Therefore, the transfer by a municipal district of all its powers and all responsibilities to one or more of the Commonwealth is inadmissible [1].

Since the Federal Constitutional Law reform in 1948, the Accounting Chamber has been responsible for auditing the municipalities' accounts. This applies, mutatis mutandis, the same auditing standards as those set for municipalities with a population of more than 20,000 people (socalled "large municipalities"). At the same time, the Accounting Chamber acts as a body of the autonomous Parliament of the province in which a commonwealth is registered. The Accounting Chamber is obliged to audit the accounts not only of the Commonwealth as such but also of charitable and financial funds, institutions and enterprises in which the share of the Commonwealth (alone or jointly with other organizations controlled by the Accounting Chamber) is at least $50 \%$ of the authorized or subscribed capital or equity. The inspections also apply to those enterprises in which the Commonwealth occupies a dominant position in financial, economic or administrative terms [3, p. 22].

Thus, the Republic of Austria, with its wellestablished system of state financial control, which is represented by the Court of Auditors, is authorized to conduct an audit not only of the state economy of the Federation but also to audit the finances of the federal states, and financial activities related to charitable and other funds and institutions managed by the Federation. There is a coherent system of state and municipal financial control based on unified principles and standards.

A similar system of state and municipal control is built in Great Britain. Like the Austrian system, it is based on shared principles and standards, provides systematic work and interaction of SFC bodies, and creates an organizational and methodological basis for specialization and cooperation.

One of the best examples of the SFC organization based on the presidential model is the United States of America's experience. In the United States, due to the current principle of separation of powers, the highest control bodies exist in each government branch and ensure the balance of management of the executive and legislative branches. In the executive branch, the issues of financial control are dealt with by the Administrative and Budgetary Department, which, among other things, evaluates the effectiveness of organizational and management structures and coordinates their activities. In the legislative branch of government, the SFC body is the Government Accountability Office (GAO) in Congress. The GAO has broad powers to oversee all government programs and contracts and conduct research to evaluate proposed programs' effectiveness.

In France, public financial control organizations are characterized by a high degree of centralization and tight vertical inter-departmental links. The functions of state financial control are performed in particular by the Accounting Chamber, which pays special attention to the correctness, economic efficiency and compliance of reporting 
standards. It is responsible for detecting and preventing budget and financial abuse, assisting Parliament and the government to monitor the financial law's implementation [3]. In France, an essential role in managing centralized financial resources is played by specialized government entities, such as the National Credit Council, the Banking Control Commission, the Commission for Economic and Regional Development. Recently, the SFC of France is expanding towards assessing the effectiveness of budget funds and assessing the various government agencies efficiency.

The following example of the public financial control system organization is the Swedish experience. The economy of this country among the EU countries is more socially oriented. The public financial control system over the use of budget funds in Sweden consists of three levels: national, district and municipal [2].

In the early 1960th in Sweden, a new method of control was originated - "efficiency control", currently used by all civilized countries. During the performance audit, special attention is paid to assessing the consequences of government decisions on the state budget [2]. The Swedish government believes that determining the public authority's effectiveness contributes to budget funds' economic and socially efficient spending. The results of both the financial and performance audits have to be reflected in the detailed report. All audit reports go to one of the responsible Auditors General, who then decides which ones to submit to Parliament. In the future, the reports are published in open resources and can be studied by anyone.

Therefore, considering developed countries' experience, one can conclude that the primary condition for practical and operational control is the presence of territorial units, which, depending on the form of government, are fully or partially subordinated to the Supreme Audit Office. They perform their functions independently and focus on the local budget expenditure check, and, if necessary, carry out the central control body's operational tasks. Similar regional offices of the supreme body of state control operate in Germany, Canada, Mongolia, Bulgaria, Brazil, Poland, China, the Czech Republic, etc.

The general features of optimization and compliance with EU requirements, models of the Ukrainian system of financial control at the local level (municipal financial management) presuppose the following: [5]:

1) external independent financial control, in terms of general independent control over budget revenues at all levels and expenditure of budget funds, including local budgets and transfers, ought to be carried out by the Accounting Chamber and its regional offices;

2) internal financial control, in terms of control over the timely and complete receipt of taxes, fees (mandatory payments) to the budgets of all levels - the Ministry of Finance, in particular, the State Fiscal Service of Ukraine, the Customs
Service of Ukraine within the Ministry, and other authorized authorities;

3) internal financial control (control over the expenditure of local budgets and transfers from local budgets); internal control and audit services within local authorities (municipal control bodies) and auditors in budgetary institutions; control over the use of transfers from the state budget to local budgets - authorized representatives (state auditors) of the Minister of Finance.

Not all financial control measures at the local level will significantly improve financial and budgetary discipline. In this regard, it is necessary to clearly define the municipal financial control model and its implementation stages, develop a legal framework, and make financial and economic calculations of such a model.

Conclusions. Consequently, the above examples show that several regulatory authorities represent the SFC system in foreign countries. In addition, there is a transparent hierarchical system: headed by the Supreme Audit Institution, which has the most powers and rights; all others are either subordinate to it or are subject to coordination and verification for compliance and efficiency on its part. Such an organization of control in Ukraine will increase SFC bodies' efficiency, reduce chaos, and allow crime prevention at the state and local levels. Due to the state's decentralization, the need for a well-established public financial control system is a priority because it is the SFC at all government levels that can ensure the proper use of funds.

Foreign experience demonstrates that state financial control bodies can effectively exist and function based on mutually exclusive approaches from centralization and decentralization positions. However, common tasks and shared principles in the organization of control bodies taking into account national specifics, economic conditions, and historical development act as a basis and provide effective public financial resources management.

Therefore, the reform of state financial control under the practical foreign experience must be Ukraine's integration process components into the European community aligned with ensuring the public finance management effectiveness.

\section{REFERENCES:}

1. Zhurakovskyi T. The problem of determination of public financial control in current conditions. Available at: http://academy.gov.ua/ej/ej10/doc_pdf/Zhurakovskyy.pdf

2. Levchuk Y. (2019) The essence of the concept of "financial control". Management of socio-economic transformations of economic processes: realities and challenges: materials of the International scientific-practical conference (pp. 234-236). April 18-19, Mukachevo, Ukraine.

3. Akhunova Ye.A. Financial control as an element of management of finance and state financial regulation. Journal of Economy and Business, no. 5-2, pp. 6-8.

4. Svistun D. (2019) The essence and objectives of public financial control. Scientific Opinion of the present and the fu- 
ture: a collection of articles by participants of the twenty-ninth All-Ukrainian practical-cognitive conference (pp. 23-25). April 29 - May 7. Dnipro, Ukraine.

5. Goloyadova T. (2014) International experience of the highest bodies of public financial control in the United States, France, Great Britain, Germany and prospects for the public financial control development in Ukraine. Scientific Bulletin of the International Humanities University, no. 11, pp. 105-107.

6. Lima Declaration of Guidelines on Auditing. (1977). Available at: https://zakon.rada.gov.ua/laws/show/604_001\#Text.

\section{БІБЛІОГРАФІЧНИЙ СПИСОК:}

1. Жураковський, де Сас Т. Б. Проблема детермінації державного фінансового контролю в сучасних умовах. URL: http://academy.gov.ua/ej/ej10/doc_pdf/Zhurakovskyy.pdf.

2. Левчук Ю. Сутність поняття «фрінансовий контроль». Управління соціально-економічними трансформаціями господарських процесів: реалії і виклики : збірник тез доповідей Міжнародної науково-практичної конференції (с. 234-236) 18-19 квітня, 2019, Мукачево, Україна.

3. Akhunova Ye. A. Financial control as an element of management of finance and state financial regulation. Journal of Economy and Business. № 5-2. P. 6-8.

4. Свистун Д. Сутність та завдання державного фрінансового контролю. Наукова думка сучасності і майбутнього : збірник статей учасників двадцять дев'ятої всеукраїнської практично-пізнавальної конфреренції (с. 23-25) 29 квітня 7 травня, 2019, Дніпро, Україна.

5. Голоядова Т.О. Міжнародний досвід вищих органів державного фінансового контролю США, Франції, Великобританії, Німеччини та перспективи розвитку державного фінансового контролю в Україні. Науковий вісник Міжнародного гуманітарного університету. 2014. № 11. С. 105-107.

6. Лімська декларація керівних принципів контролю. 1977. URL: https://zakon.rada.gov.ua/laws/show/604_001\#Text. 